\title{
酸素活性污泥法による製紙排水の処理
}

\author{
昭和エンジニアリング株式会社川崎研究センター 本田 一好 \\ 同 環境事業本部 植 田 誠, 竹倉 紘一
}

\section{Waste Water Treatment in Pulp and Paper with High Purity Oxygen Activated Sludge System (UNOX System)}

\author{
Kazuyoshi Honda*, Makoto Ueda and Koichi Takekura \\ Showa Engineering Co., Ltd., Enviromental Business Headquarters, *Kawasaki Research Center
}

\begin{abstract}
A lot of UNOX System have been employed in various indistrial field, about 30 plants for pulp and paper industries in Japan.

In this paper,we report the treatment performance of UNOX System on board-paper waste, DIP waste, KP waste and KP waste plus EVA drain with the data of actual plants and treatability tests. At the same time, we mention the case of adding of coagulant agent into aeration tank for reference. Removal efficiency of not only BOD and COD but also even AOX are remarkable.
\end{abstract}

\section{1.はじめに}

活性污泥法において，曝気用ガスを空気に替えて高 濃度酸素を用いる酸素活性污泥法がわが国で昭和 47 年, 初めて実設備が稼働したのは，ユノックス・シス テムと呼ばれる密閉多段槽式酸素活性污泥法である。

ユノックス・システムは現在では，製紙排水，石油 化学排水, 食品排水に代表される産業排水 ${ }^{1)}$ から下水, し尿の家庭排水まで広く採用されている。1995 年現 在で全世界では 300 基以上の実設備が稼働している。 わが国では, 約 100 基が稼働しているが，その内 28 基が製紙排水処理に採用されている。

ここでは, 最近実施した処理試験と実設備運転デー 夕より，板紙， DIP, KP+EVA, KP の各排水につ いてユノックス・システムの処理性能を報告する。

\section{2. ユノックス・システムと产の特徵}

図1にユノックス・システムの一般的なフローシー 卜を示す。実設備の例を（写真）に示す。

本システムは酸素発生装置, 各段に表面曝気機を備 之た密閉多段槽式の曝気槽と沈殿槽から構成される。

曝気槽は通常 2 4 段の多段に仕切られ, 酸素ガス と活性污泥混合液は各段を並流し, 排ガスは最終段よ り大気に放出される。曝気槽各段には液相の溶存酸素
濃度（DO）が $3 \sim 10 \mathrm{mg} / l$ となるように設計された 表面曝気機が設けられている。

酸素発生装置からの酸素がスは，曝気槽内の気相圧 力が通常 $50 \mathrm{mmAq}$ 程度となるように，圧力制御され て曝気槽第 1 段に供給される。曝気槽内での酸素要求 量が増大すれば，気相の酸素は液相に溶解し，気相の 圧力が低下する。この圧力を補うために酸素がス供給 弁が開き，所定の気相圧力になるまで酸素が供給され る。最終段には排ガスの酸素濃度分析計と排ガス流量 調節弁が設置されており，排ガスの酸素濃度が 35 45\%程度となるように排がス流量調節弁の開度を設定 する。排ガス酸素濃度と DO の間には相関関係がある ので，酸素ガス濃度での運転監視が可能である。

図 1 のフローシートには最近注目されているオゾン 処理による脱色, COD 除去, 消毒を行う場合につい ても付記されている2)。曝気に使用する酸素を用いて オゾンを安価に発生させ，オゾン処理後の排ガスを無 駄無く曝気用の酸素として再利用する方式である。本 方式はすでに下水，し尿，染色排水の処理に実設備が 稼㗢している。

ユノックス・システムの特徴を列記する。

（1）処理の安定性

流入負荷の変動に対して酸素がス供給が自動調節さ れかつ DO が高いので，排水の負荷変動への対応が強 


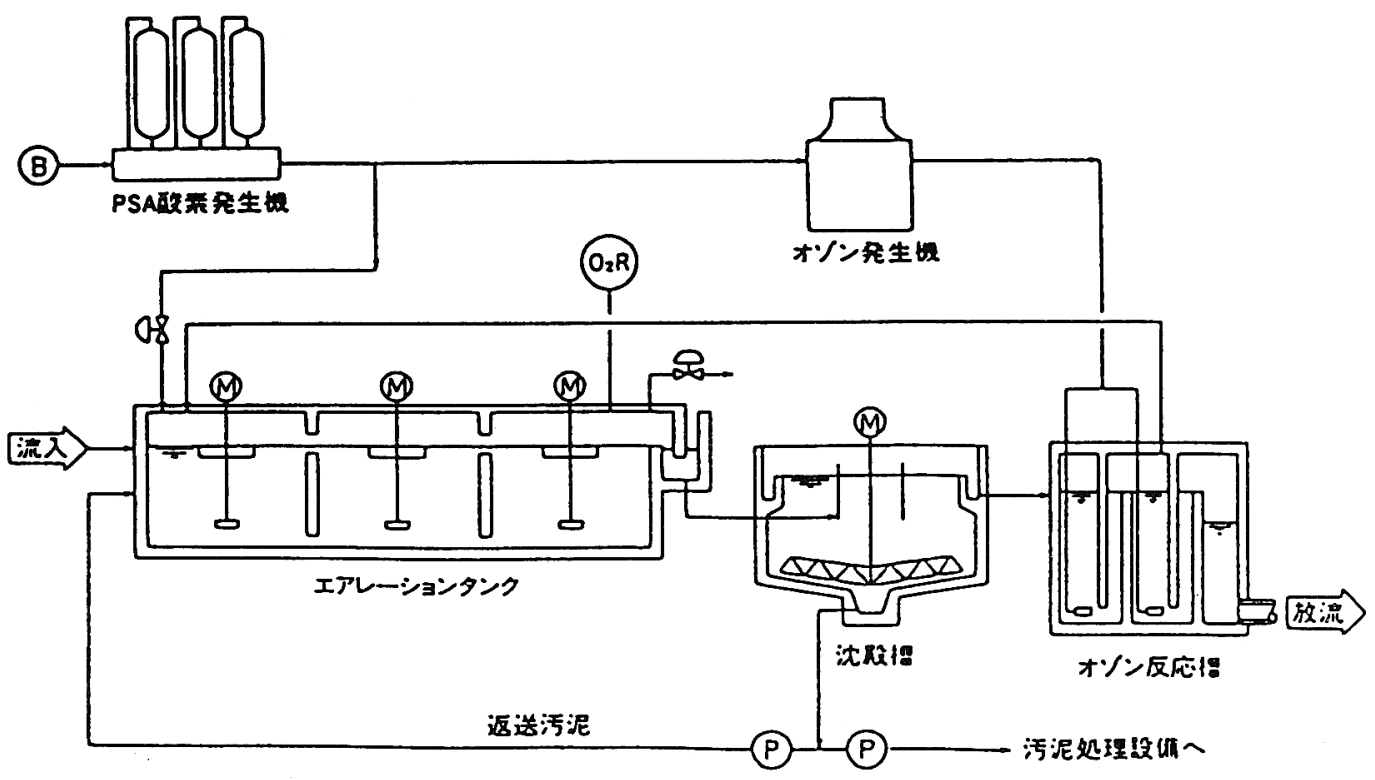

図 1 ユノックス法とオゾン処理の組み合わせ

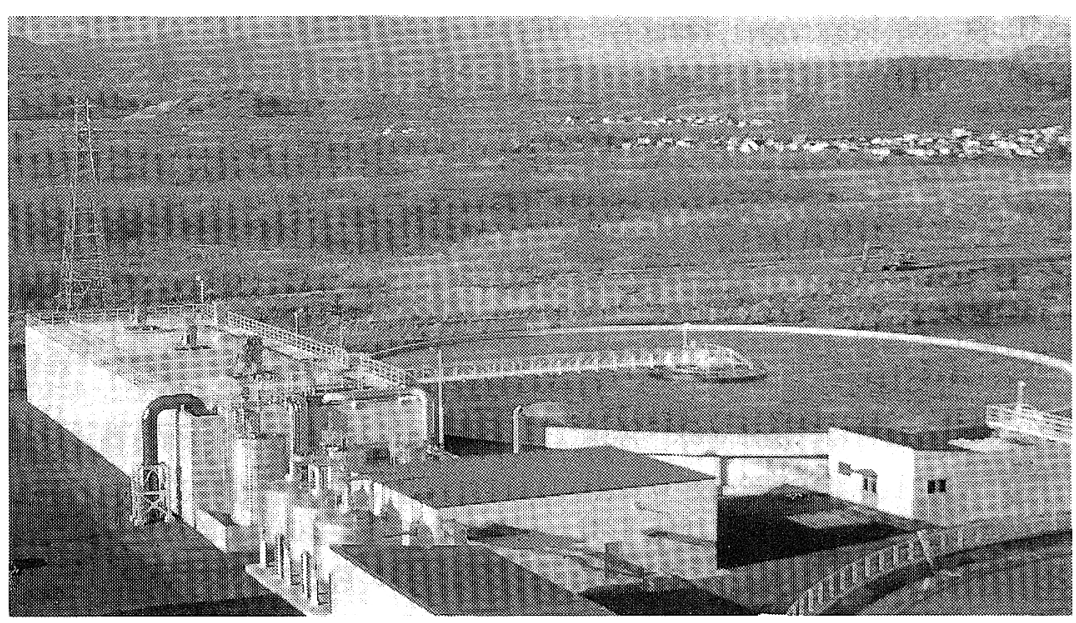

(写真) 水処理施設全景

\section{く，処理が安定する。}

\section{(2) 敷地面積の削減}

高 DO, 高濃度污泥 (MLSS) での運転のため, 容 積負荷が従来の空気曝気活性污泥法の 2 3 倍と高く とれる。

\section{（3）污泥性状の改善}

DO が高いため, 污泥の沈降性と圧密性が良好にな り，沈港槽の污泥管理が容易である。高 DOのため污 泥の自己酸化が進み, 余剩污泥量が少なく, 脱水性に 優れている。

（4）二次公害の防止
曝気槽が密閉槽なため，泡や飛沫の飛散が無い。酸 素がスが密閉多段槽で繰り返し活性污泥に溶解するの で，㚖気が分解され，かつ排がス量も通常の空気曝気 活性污泥法の $1 / 200$ と少ない。

\section{3. 処理結果の概要}

（表）に今回取り上げる 4 種類の排水の処理結果の 概要を示市。SS 込みの分析值を T-BOD, T-CODで 示し, No.5 A 万紙のろ液の分析值を F-BOD, F-COD で示す。

表より，各排水とも処理水 $\mathrm{F}-\mathrm{BOD}$ はいずれも一桁 
（表）製紙排水の酸素曝気活性污泥処理例

\begin{tabular}{|c|c|c|c|c|c|c|c|c|}
\hline \multirow{2}{*}{ 項 目 } & \multirow{2}{*}{\multicolumn{2}{|c|}{ 排水の種類 }} & \multicolumn{2}{|c|}{ 板紙排水 } & \multirow{3}{*}{$\begin{array}{c}\text { DIP 排水 } \\
175 / 155\end{array}$} & \multicolumn{2}{|c|}{$\mathrm{KP}+\mathrm{EVA}$ 排水 } & \multirow{3}{*}{$\begin{array}{l}\mathrm{KP} \text { 排水 } \\
200 / 180\end{array}$} \\
\hline & & & & 凝集剤添加 & & & 凝集剂添加 & \\
\hline \multirow{2}{*}{$\mathrm{T}-\mathrm{BOD} / \mathrm{F}-\mathrm{BOD}$} & 流入水 & $\mathrm{mg} / \mathrm{l}$ & $170 / 140$ & $170 / 140$ & & $720 / 630$ & $730 / 690$ & \\
\hline & 処理水 & $\mathrm{mg} / \mathrm{l}$ & $13 / 4$ & $13 / 4$ & $14 / 6$ & $15 / 6$ & $8 / 7$ & $15 / 7$ \\
\hline \multirow{2}{*}{$\mathrm{T}-\mathrm{COD} / \mathrm{F}-\mathrm{COD}$} & 流入水 & $\mathrm{mg} / \mathrm{l}$ & $180 / 150$ & $180 / 150$ & $215 / 175$ & $810 / 800$ & $735 / 700$ & $250 / 220$ \\
\hline & 処理水 & $\mathrm{mg} / \mathrm{l}$ & $45 / 38$ & $37 / 35$ & $92 / 83$ & $220 / 205$ & $155 / 140$ & $105 / 95$ \\
\hline \multirow{2}{*}{ SS } & 流入水 & $\mathrm{mg} / \mathrm{l}$ & 80 & 80 & 120 & 35 & 45 & 115 \\
\hline & 処理水 & $\mathrm{mg} / \mathrm{l}$ & 22 & 16 & 50 & 60 & 63 & 40 \\
\hline \multicolumn{2}{|l|}{ MLSS } & $\mathrm{mg} / \mathrm{l}$ & 4,800 & 4,800 & 5,600 & 5,300 & 5,100 & 5,600 \\
\hline \multicolumn{2}{|l|}{ MLVSS/MSLL } & $\%$ & 87 & 84 & 59 & 93 & 84 & 88 \\
\hline \multicolumn{2}{|l|}{ SVI } & $\mathrm{m} l / \mathrm{g}$ & 140 & 45 & 65 & 125 & 50 & 55 \\
\hline \multirow{2}{*}{ 曝気槽出口凝集剂添加率 } & $\mathrm{Al}_{2} \mathrm{O}_{3}$ & $\mathrm{mg} / \mathrm{l}$ & - & 35 & - & - & 18 & - \\
\hline & ポリマー & $\mathrm{mg} / \mathrm{l}$ & - & 1 & - & - & 1.3 & - \\
\hline \multicolumn{3}{|l|}{ 備 考 } & \multicolumn{2}{|c|}{ 流入水は前凝沈処理水 } & 同左 & & & \\
\hline
\end{tabular}

(注) T：SS を含む分析值，F：はNo.5 A 万紙のろ液の分析值を示す。

と完全に生物酸化が完了しているにも拘わらず，処理 水 F-COD は排水の種類によって大きく異なる。污泥 の沈降性を示す指標である SVIも排水の種類によっ て異なることが分かる。なお，曝気槽出口の凝集剤を 添加した場合については後述する。

\section{COD 除去性能}

図 2 にCOD 污泥負荷と除去 COD 污泥負荷の関係 を示す。図の直線の公配が COD 除去率を示す。

COD 污泥負荷を算定する場合の污泥濃度には，一 般にはMLSS を採用しているが，表に見るごとく排 水の種類によって MLVSS/MLSS 比が大幅に異なっ ている。したがって，活性污泥中の有効成分に近い MLVSS を用いてCOD 污泥負荷を示している。例えば, DIP 排水では流入排水中の無機質が污泥中に蓄積す るために, MLVSS/MLSS 比は $60 \%$ 程度と低く, KP $+E V A$ 排水では流入 SS が低濃度なため, MLVSS/ MLSS 比は $90 \%$ 以上と高い。すなわち，MLSS 当た りの污泥負荷が同じでも，MLVSS当たりの污泥負 荷では DIP 排水の方が KP+EVA 排水より約 $50 \%$ 高 いことになる。

図 2 より，板紙排水の場合は COD 污泥負荷は 0.9 $\mathrm{kgCOD} / \mathrm{kgMLVSS}$ ・D まで勾配は直線上にある。す なわち，除去率の低下は認められず，平均除去率は

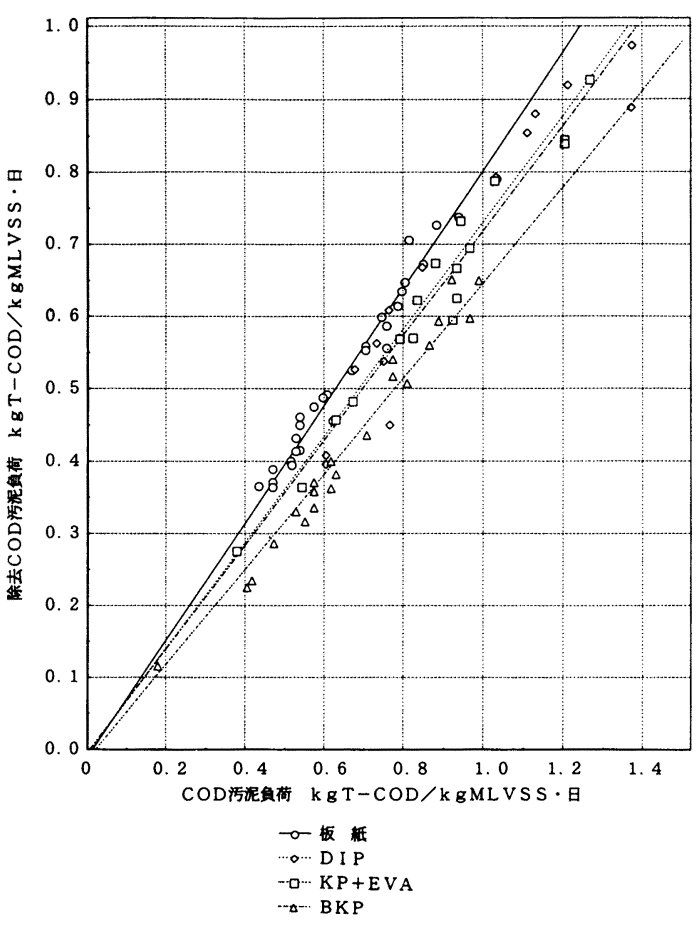

図 $2 \mathrm{COD}$ 污泥負荷と COD 除去率の関係 
81\%である。

同様に DIP 排水では COD の平均除去率は $74 \%$ で あるが, COD 污泥負荷が $0.8 \sim 1.2 \mathrm{kgCOD} / \mathrm{kg}$ MLVSS・D の範囲では直線の上にあり，板紙排水の 除去率に近い除去率を示している。

$\mathrm{KP}+\mathrm{EVA}$ 排水では変動幅が大きいが, $\mathrm{COD}$ 污泥 負荷は $1.2 \mathrm{kgCOD} / \mathrm{kgMLVSS} \cdot \mathrm{D}$ 付近まで約 $72 \%$ の除去率を達成している。

$\mathrm{KP}$ 排水では COD 污泥負荷は $1.0 \mathrm{kgCOD} / \mathrm{kg}$ MLVSS・D 付近まで除去率 $66 \%$ を示している。

$\mathrm{KP}$ と $\mathrm{KP}+\mathrm{EVA}$ 排水では低負荷よりも高負荷側 の方が除去率が向上する傾向が見られる。これは製紙 工程の排水量と濃度の増加時には, 生物処理の比較的 容易な成分が増加する傾向があることを伺わせている。

図 3 にはCOD 容積負荷と除去 COD 容積負荷の関 係を示す。図 2 と同様に勾配が COD 除去率を示す。 各排水について, COD 污泥負荷と COD 除去率の関 係と同様な傾向を示している。いずれも，高負荷運転 時でも安定した COD 除去性能が得られている。上記 の COD 污泥負荷に相当する COD 容積負荷を列記す る。

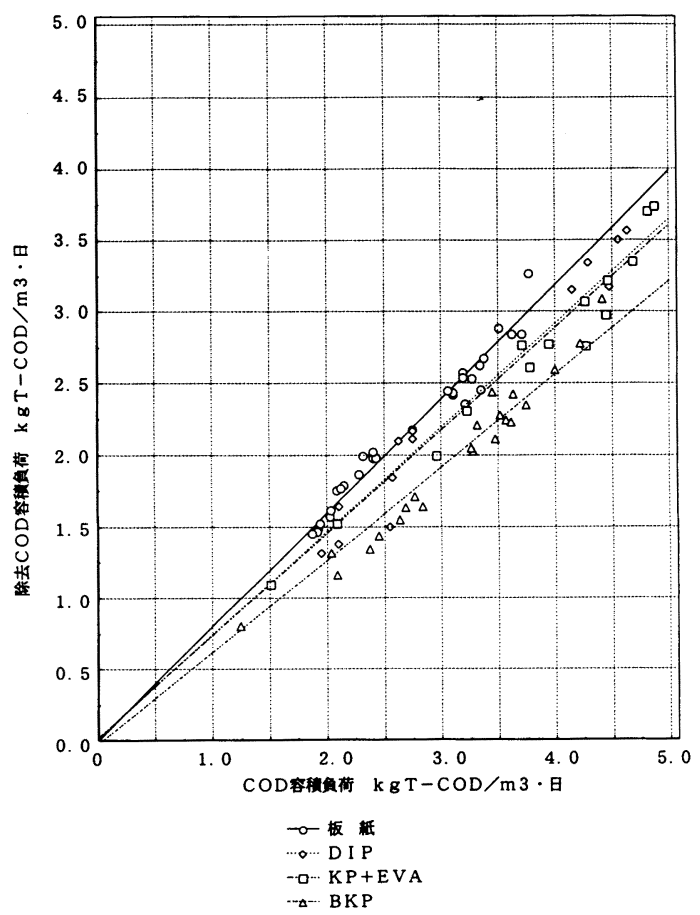

図 $3 \mathrm{COD}$ 容積負荷と COD 除去率の関係
COD 除去率が一定な真荷範囲

COD 污泥負荷

COD 容積負荷

$(\mathrm{kgCOD} / \mathrm{kgMLVSS} \cdot \mathrm{D})$

板紙排水

0.9

$\underline{\left(\mathrm{kgCOD} / \mathrm{m}^{3} \cdot \mathrm{D}\right)}$

DIP 排水

1.2

3.5

$\mathrm{KP}+\mathrm{EVA}$

1.2

4.5

$\mathrm{KP}$ 排水

1.0

4.7

4.5

\section{BOD 除去性能}

BOD 污泥負荷と除去 BOD 污泥負荷の関係を図 4 に示す。勾配が BOD 除去率を示す。

BOD は生物分解可能な有機物の濃度を示すので, COD に比べて除去率が高く, 高負荷領域まで除去率 が一定なことを示している。

図 4 は T-BOD 基準で表示しているが, 表に示し たように, SS を除いた処理水の F-BOD はいずれも $10 \mathrm{mg} / l$ 以下 $(4 \sim 7 \mathrm{mg} / l)$ なので, 生物分解可能な 物質はほぼ完全に除去されている。したがって, 前述 の COD 除去率は活性污泥法の限界值を示していると 言える。

図 4 の BOD 污泥負荷の最大值と BOD 除去率を列 記する。

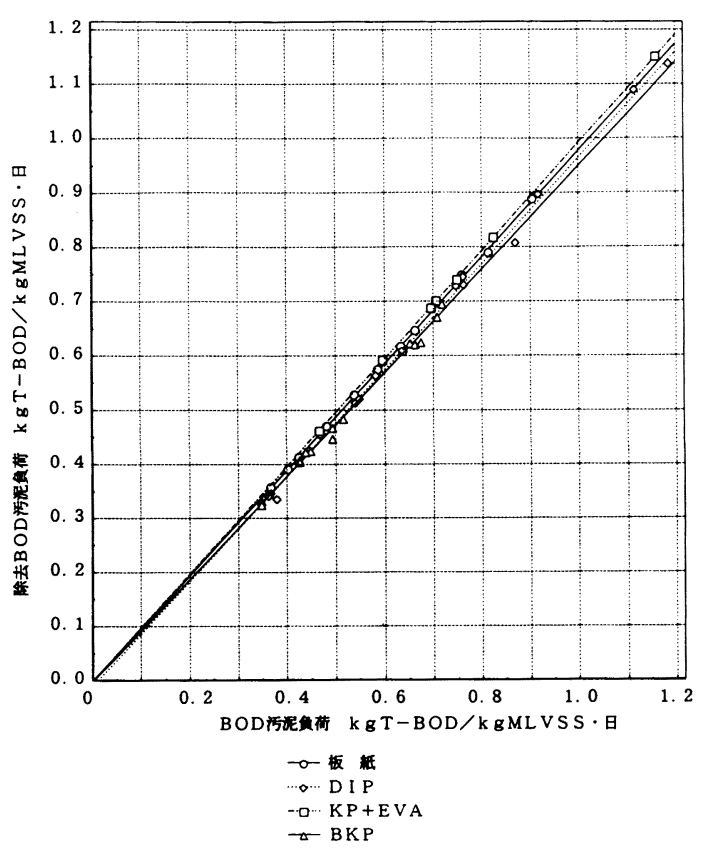

図 4 BOD 污泥負荷と BOD 除去率の関係 
最大 BOD 污泥負荷 BOD 除去率 $(\mathrm{kgBOD} / \mathrm{kgMLVSS} \cdot \mathrm{D}) \quad(\%)$

板紙排水 0.9

98.0

DIP 排水

1.2

97.7

$\mathrm{KP}+\mathrm{EVA}$

1.15

99.4

$\mathrm{KP}$ 排水

0.7

95.4

図 5 には BOD 容積負荷と除去 BOD 容積負荷の関 係を示す。図中の最大 BOD 容積負荷を列記する。 最大 BOD 容積負荷 BOD 除去率 $\left(\mathrm{kgBOD} / \mathrm{m}^{3} \cdot \mathrm{D}\right)$

板紙排水 3.5

98.0

DIP 排水

3.8

97.7

$\mathrm{KP}+\mathrm{EVA}$

5.1

99.4

$\mathrm{KP}$ 排水

3.4

95.4

\section{AOX 除去性能}

ダイオキシンとの関連で排水中の AOX 削減が重要 な課題となっている。図6にユノックス・システムに おける COD と AOX 除去率の関係を示す。

一般に AOX の除去率は CODの除去率に比例する とされている。四6では KP+EVA 排水について, $\mathrm{AOX}$ とCODの除去率はほぼ等しいことを示してい

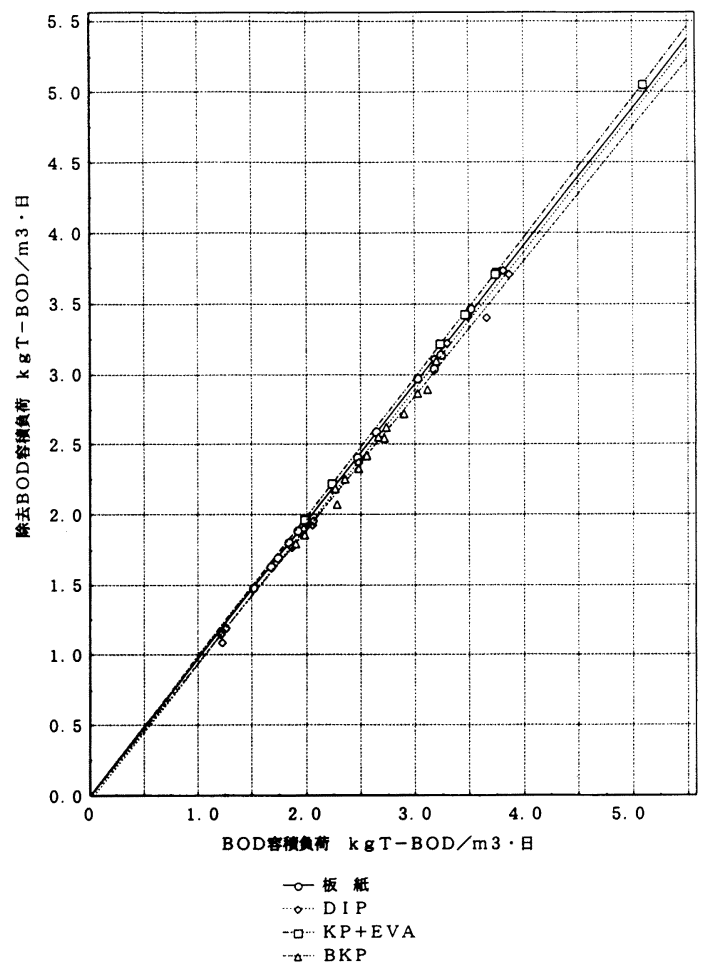

図 5 BOD 容積負荷と BOD 除去率の関倸

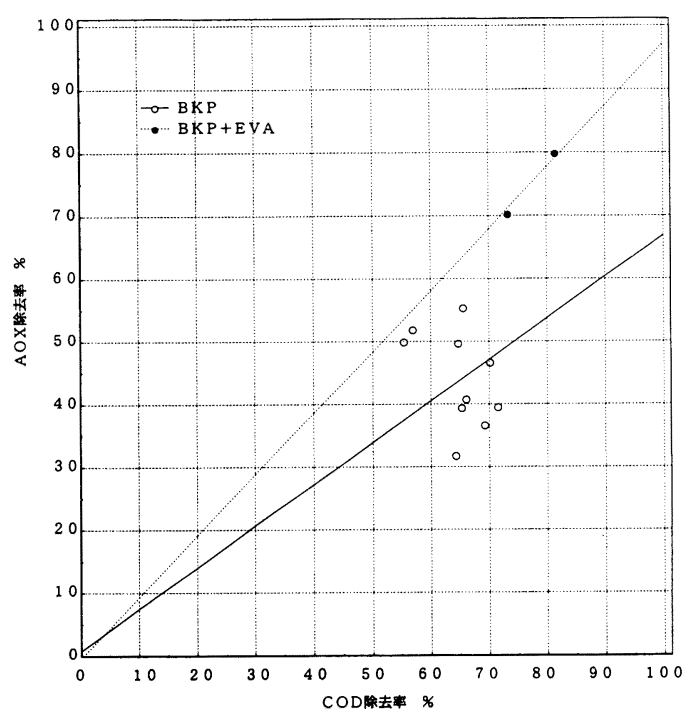

図 $6 \mathrm{COD}$ と AOX 除去率の関係

る。 $\mathrm{KP}$ 排水では $\mathrm{AOX}$ と $\mathrm{COD}$ 除去率の相関倸数は 0.66 であるが，変動が大きい。KP 排水のデー夕は 過去 3 年間に渡るもので，年々，原水 COD とともに $\mathrm{AOX}$ も低下し, 現在の活性污泥処理水の AOX は大 幅に削減されている。

原水の COD が高い時，すなわち原水の AOX が高 い時ほど, AOX の除去率が高く, AOX は T-COD より, F-COD との相関が強い傾向が見られた。

ユノックス・システムの処理水の凝集処理による $\mathrm{AOX}$ の除去性能の例を以下に示す。

\begin{tabular}{cccc}
$8 \%$ 硫酸バンド & \multicolumn{2}{c}{ AOX } & COD \\
添加率 & 濃度 & 除去率 & 除去率 \\
$(\mathrm{mg} / l)$ & $(\mathrm{mg} / l)$ & $(\%)$ & $(\%)$ \\
0 & 23 & - & - \\
200 & 18 & 21.7 & - \\
300 & 2 & 91.3 & 30
\end{tabular}

AOX の除去性能については，データの蓄積が少な いので，個々の排水につて分析を実施する必要が有る のが現状である。

\section{7. 凝集剤添加活性污泥}

活性污泥法の実設備において, 污泥の沈降性改善, 処理水質改善および水量の過負荷対策等の対応として, 曝気槽出口や沈澱槽に硫酸バンド等の無機凝集剤や高 分子凝集剤（ポリマー）を添加する方法が従来より実 施されている。

主に沈澱槽の敷地削減のために污泥沈降性の向上を 目的とした凝集鼡添加の例を報告する。無機凝集剤と 
して硫酸バンドを曝気槽流出配管に，アニオン系ポリ マーをその下流に設置しな凝集槽に注入した。

(1) 凝集剤添加によるCOD 除去効果

図 7 に $\mathrm{KP}+\mathrm{EVA}$ 排水の処理における凝集剤添 加の有無による COD 除去性能の差を示す。

凝集剤添加の経過は次の通りである。なお, 硫酸バ ンドの注入率は $\mathrm{Al}_{2} \mathrm{O}_{3}$ 基準で示す。

$\begin{array}{ccc} & \begin{array}{c}\text { 硫酸バンド } \\ (\mathrm{mg} / \mathrm{l})\end{array} & \begin{array}{c}\text { ポリマー } \\ (\mathrm{mg} / \mathrm{l})\end{array} \\ \text { 当 初 } & 25 & 1.8 \\ \text { 変 更 } & 18 & 1.3\end{array}$

凝集剤削減によるCOD 除去率の差が認められない ので, 図 7 には変更後のデー夕を示す。凝集剤添加に より COD 污泥負荷が高くなっているのは, MLSS 設 定を同一としたため，凝集剤添加によりMLVSS/ MLSS 比が 93\%から 84\%に低下したためである。

凝集剂添加により，COD 除去率は $71 \%$ から $81 \%$ に 上昇し, かつ除去率が安定している。BOD 除去率は 前述のように凝集剤無添加でも $99 \%$ 以上達成してい るので, 凝集剤添加の有無による差は認められない。

(2) 凝集剂添加による污泥沈降性の向上.

無機凝集㘊を添加した場合, 污泥中の無機質の割合 が増加して, MLVSS/MLSS 比が低下する。すなわち, 污泥の比重が増加する。さらに, ポリマーを添加する

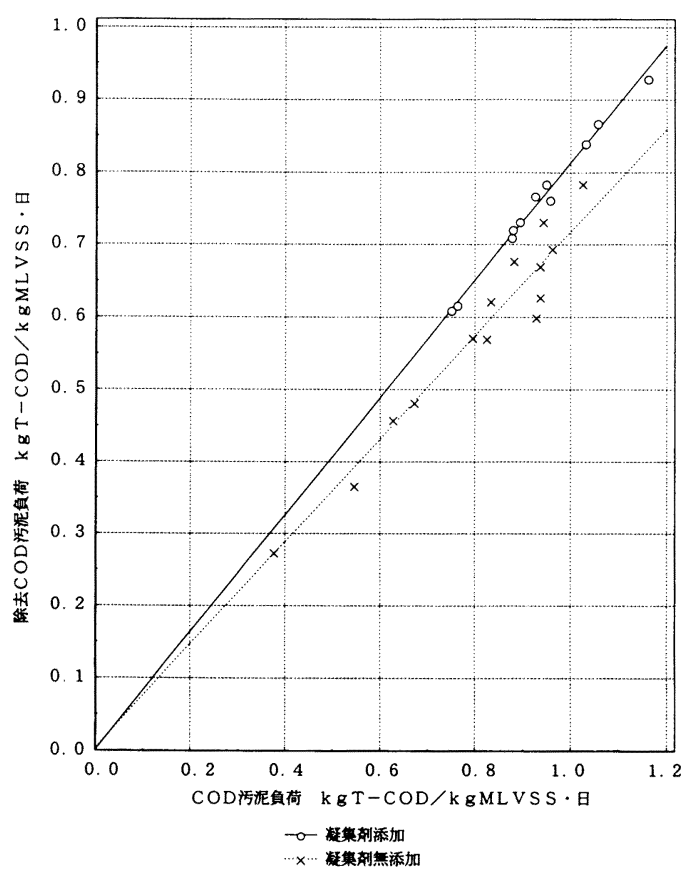

図 7 凝集剂添加の効果
ことによって，污泥フロック径が増大し，比重の增加 との相乗効果で污泥の沈降性が向.上する。

実設備の運転管理上は, 污泥の沈降性を示す指標上 して, 污泥の 30 分静置後の汇泥容積 $\mathrm{SV}_{30}$ から求め たSVIが多く使用されている。一般にSVIは100以 下では沈降性が良好と判定されている。

沈澱槽の計画設計上は, 活泥の初期沈降速度を測定 することが重要である。図８に凝集剂添加の有無によ る污泥の沈降速度を污泥濃度に対して亦す。网から分 かるように, 凝集剂添加により, 污泥の沈降速度が 2 倍以上向上している。

\section{8. 排ガスと処理水の臭気}

活性污泥法の二次公害として, 排がスと処理水の臭 気が重要なテーマとなっている。ユノックス・システ ムでの測定例を以下に示す。

硫化水素 硫 化 二硫化 メチルメルカ メチルメチル プタン

排ガス ND ND ND ND

処理水 0.0010 ND ND 0.0008

(単位: 排ガス $\mathrm{ppm}$, 処理水 $\mathrm{mg} / \mathrm{l}$ )

ユノックス・システムでは酸素がスが曝気槽内で繰 り返し活性活泥に溶解するために, 排がスの血気が政 めて低い。高 DO 下で生物酸化が十分に進むために, 処理水中の臭気成分も低レベルである。

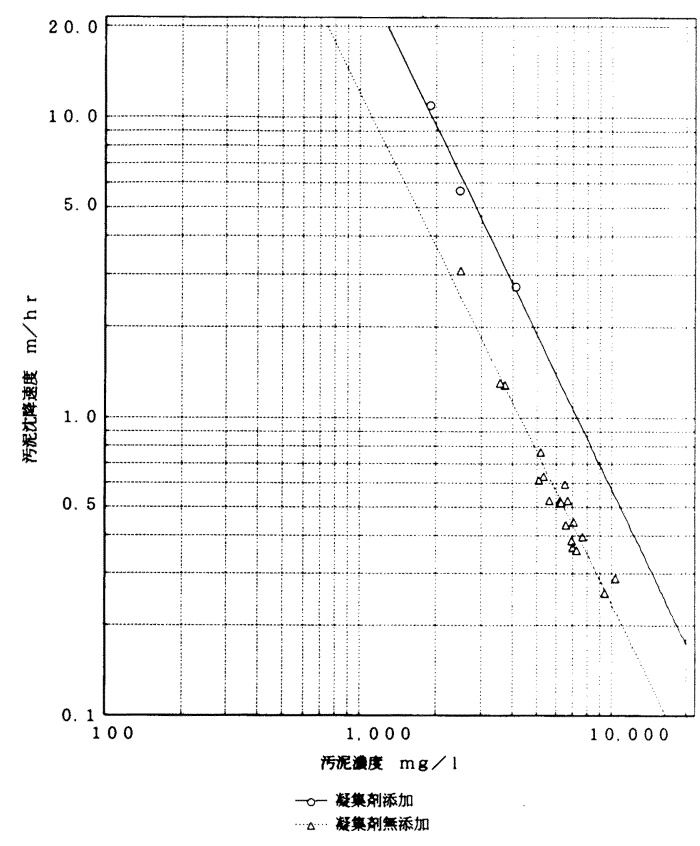

図 8 汗泥沈降速度 


\section{9. 酸素消費量}

活性活泥法に打ける酸素消費星の相関式は次式で与 えられる。
$\mathrm{O}_{2} / \mathrm{BOD}=\mathrm{A}+\mathrm{B} /(\mathrm{F} / \mathrm{M})$

ここで,
$\mathrm{O}_{2} / \mathrm{BOD} ： \mathrm{BOD}$ 当たりの酸素消費量 $\left(\mathrm{kgO}_{2} / \mathrm{kgBOD}\right)$

$\mathbf{F} / \mathbf{M}: \mathrm{BOD}$ 污泥負荷 $(\mathrm{kgBOD} / \mathrm{kgMLSS} \cdot \mathrm{D})$

$\mathrm{A}, \mathrm{B}:$ : 係数

不辺の第 1 项は BOD の酸化に必要な酸素量を示し, 第2 項は活性汇泷向身の戊酸化に消費される酸素量 在示亦。 $\mathrm{A}, \mathrm{B}$ とも活性污泥で処理される流入排水の 性状に影響される係数である。

$\mathrm{KP}$ 排水を処理するユノックス・システムの実設備 での酸素消費量のデータを図 9 に示す。ここで酸素消 費量は供給酸素量から排ガス中の酸素量を差し引いて 求为な值である。!:䛉の相関式の係数は， $\mathrm{A}=1.0$, $\mathrm{B}=0.13$ となる。一般的な排水では, $\mathrm{A} の$ 值は 0.45 〜0.8の範津が多いが, KP 排水の場合は BOD 酸化 に必要な酸素荲が敬好て高いのが特徵である。

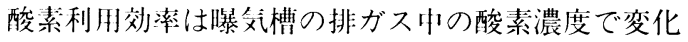
する。实設備の测定例を図 10 に示す。通常の排ガス 中つ酸素濃度の設定佰は 35 45\%につき，酸素利用 効摔は 85 90\%程度である。

\section{0. おわりに}

ユノックス・システムによる製紙排水の COD, $\mathrm{BOD}$ および AOX の除去性能と凝集剤添加活性污泥 つ活泥沈降性について処理試験と実設備のデー夕より 解析した。

今後は阔銷水域の笛栄養化防止のための窒素, リン つ除去之和歌川市の着色水規制条例に見るように，処 理水の脱色も重要なテーマとなってくる。窒素除去に はBOD 除去以卜に大量の酸素を必要とすること，脱 色に効果が鬲いオゾン発生には酸素を使用することが 設備規模と所要電力の面で有利なこと等，今後とも酸

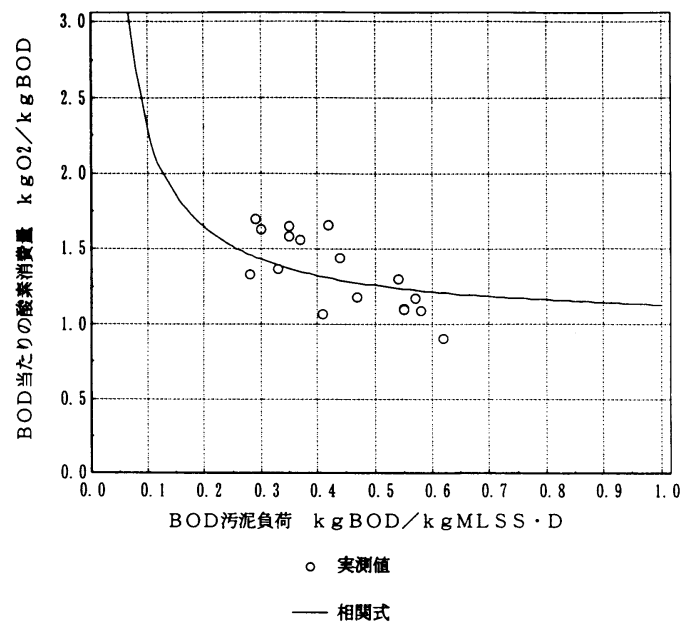

図 9 酸素消費量実測データ

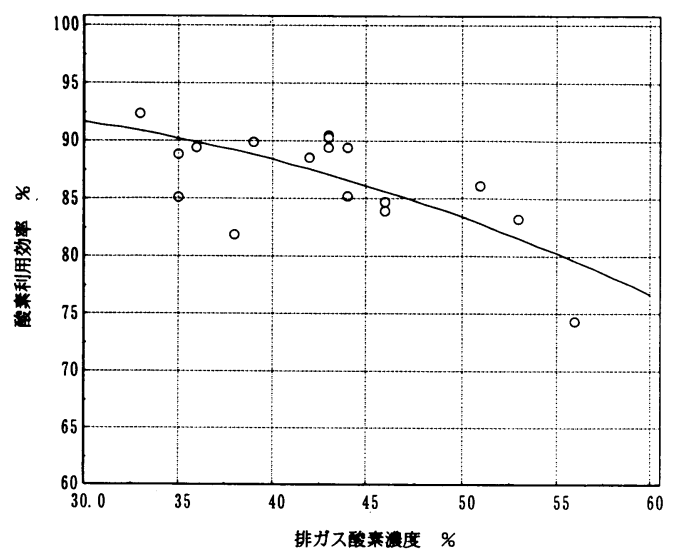

図 10 酸素利用効率

素活性污泥法の改良・進歩が不可欠である。

\section{参考文献}

1）斎藤, 竹倉, 植田, 浄光: PPM, Vol.11, No. 12, 16 (1980)

2）本田，竹倉：加工技術，Vol.29, No.8, 541 (1994) 